\title{
The "Virtuous Circle" Between Corporate Social Performance and Corporate Financial Performance in the European Banking Sector
}

\author{
Candida Bussoli ${ }^{1} \&$ Danilo Conte ${ }^{1}$ \\ ${ }^{1}$ Department of Management, LUM University, S.S. 100 km 18, 70010 Casamassima (BA), Italy \\ Correspondence: Danilo Conte, Department of Management, LUM University, S.S. 100 km 18, 70010 Casamassima \\ (BA), Italy.
}

Received: February 8, 2018

Accepted: February 23, $2018 \quad$ Online Published: February 28, 2018

doi:10.5430/ijba.v9n2p80

URL: https://doi.org/10.5430/ijba.v9n2p80

\begin{abstract}
This paper analyses the relationship between Corporate Social Performance (CSP) and Corporate Financial Performance (CFP) in the European banking sector. The good management approach and the slack resources approach have been tested, and the paper aims to verify the existence of a "virtuous circle" between the two performance measures. The econometric analysis, based on panel data, is performed on a sample of 71 listed banks (EU28) in the period between 2011 and 2015. The main findings show a positive influence of CSP on CFP, confirming the good management approach. However, the results demonstrate a negative influence of CFP on CSP, which generates the impossibility of confirming the theoretical assumptions of the slack resources approach. Therefore, the existence of a "virtuous circle" deriving from the integration of the two approaches is not supported.
\end{abstract}

Keywords: corporate social responsibility, European banking sector, financial performance

\section{Introduction}

Corporate Social Responsibility (CSR), as a strategic management method that is implemented through a multi-stakeholder logic, promotes a vision of the company that, while retaining the attention to profitability, considers the effects that the activity can generate on all partners (customers, suppliers, employees, and investors), the local community and the environment in general. Aguinis (2011), states that the CSR represents: "context-specific organizational actions and policies that take into account stakeholders expectations and the triple bottom line of economic, social and environmental performance ".

The dynamics of financial markets, in recent decades, in a context of globalisation, have led to a multidimensional approach of CSR by financial firms and banks in particular. The CSR has received attention as a tool to pursue innovation and development and to compete in the medium and long-term.

The issue has been examined by many scholars over time (Berle, 1931; Bowen, 1953; Frederick, 1960), and has assumed growing importance, becoming a fundamental pillar in the field of studies of management in recent decades (Bontis and Serenko, 2009). Scholars, over time, have analysed specific research questions about the CSR. Some authors focused on the operationalization of CSR and specific differences with similar constructs (Carroll, 1999; Waddock, 2004), other studies focused on the various measures to detect CSR (Wood, 2010). Other works have examined specific disciplines such as organizational behavior, human resource management (Aguinis and Glavas, 2012), marketing (Maignan and Ferrell, 2004); and information systems (Elliot, 2011).

Numerous studies have investigated the relationship between the corporate social performance (CSP) and the financial performance, but with inconclusive and misleading findings (Margolis and Walsh, 2003; Mishra and Suar, 2010; Vogel, 2005). Indeed, in the literature, it is possible to find a positive association (Bakar, Sheikh, and Ameer, 2010; Oeyono, Samy, and Bampton, 2011; Orlitzky, Schmidt, and Rynes, 2003), but at the same time, there are some scholars that demonstrated a negative or a neutral association between the two performance measures (Aupperle, Carroll, and Hatfield, 1985; Lima Crisóstomo, de Souza Freire, and Cortes de Vasconcellos, 2011). Some authors have outlined causes that can determine the presence of heterogeneous results (Galbreath and Shum, 2012; Griffin and Mahon, 1997; Margolis and Walsh, 2003; Rowley and Berman, 2000; Wood and Jones, 1995). Simpson and Kohers (2002) and Griffin and Mahon (1997) suggested the need to address this analysis focusing on a single sector, 
since the specific skills and external pressures found in a particular sector determine a specialisation of social and environmental activities adopted by companies.

The present work is part of this line of studies and contributes to the literature by addressing the relationships in the banking sector, which has been poorly investigated in previous studies. In particular, the theoretical assumptions of the Stakeholder Theory are tested, in order to investigate the existence of an influence of CSP on financial performance (good management approach); at the same time, the effect of financial performance on the CSP is tested (slack resources approach). The final aim of the research is to identify whether both slack resource and good management theory may be operating simultaneously, constituting the existence of a "virtuous circle" between the two performance measures, in the European banking sector (Waddock and Graves, 1997a; Nelling and Webb, 2009).

The main results show a significant and positive relationship between CSP and CFP confirming the good management approach. Simultaneously, the empirical evidence shows a negative influence of the CFP on the CSP; therefore, the slack resources approach cannot be confirmed. Consequently, is not possible to support the existence of a "virtuous circle" in the association between the two measures in the European banking system.

This study contributes to the literature on CSR in several ways. First, it uses a comprehensive time-series of CSR data relative to bank sector. In addition, previous research analysing the link between CSR and financial performance does not account for possible persistence or unobservable characteristics that may play a role in the level of CSR activity undertaken by a bank. We examine these important considerations by controlling for firm fixed-effects in our models, using a widely validated source of data on corporate social performance.

The paper is structured as follows: the second paragraph gives a brief review of the literature that leads to the research hypotheses; the third paragraph illustrates the methodology and the sample; the fourth paragraph discusses the results. The last paragraph sets forth brief conclusive assessments and the implications of the studied phenomenon.

\section{Literature Review}

The origins of CSR are linked to the General System Theory, which characterises the studies of academics throughout the 50s. Indeed, it is possible to find the first principles concerning CSR in the vision of Boulding (1956) who defined the complex organizations as an open system, intrinsically connected to a larger environment. Consequently, CSR is linked to the damages and benefits that are determined by the interaction between the organization and environment, including social, cultural, political, economic and natural dimensions.

Early academics have introduced the concept of CSR to encourage companies to take measures to solve a number of social problems. McGuire (1969) defines four approaches to CSR. The traditional approach is a vision of neoclassical economists, who state that CSR has no role in the business. The enlightened approach assumes the CSR as a fundamental activity for companies. The responsible approach maintains that CSR is a fair activity, regardless of the possibility of obtaining a profit. Finally, the confused approach simultaneously provides an ethical justification to the CSR and an expectation of gain from its implementation.

During the 1970s the search for responsibilities that companies should deploy in particular situations, without an ethical foundation, was emphasized (Frederick, 1994). This lack of the ethical basis has been filled by Carroll (1979) who identified four specific CSR domains (economic, legal, ethical, and discretionary), to which he attributes the social problems that the company should face (consumerism, environment, discrimination, product safety and shareholder).

Wood (1991) suggests that Carroll's model does not take into account the social complexity determined by the company's activity in society through its actions. He makes a classification of structural principles (legitimacy principles, public responsibility principles, discretionary principles) as inputs, social responsibility processes (environmental scanning, stakeholders management or issue management) as throughputs and, finally, outputs as a result.

The findings in the Wood model (1991) fill a lack of previous models on CSR (Carroll, 1979; Wartick and Cochran, 1985), in fact, the author intends for results or performance, the set of events that occurred due to a series of actions carried out by the company or its employees. Furthermore, Wood specifies that based on the fundamental assumptions of the Open System-Theory, the concept of result includes a series of policies, programs, practices, effects on stakeholders and impacts on society in a broad sense (Wood, 2010).

The introduction of the term "social" into business performance is due to the influence of structural-functionalist theories (Parson, 1991). Functionalist structural theorists articulate society into distinct institutions, to which 
particular functions are attributed (i.e., the economy produces and distributes goods, services and wealth; the political order governs and redistributes; the family reproduces and socializes). Each institution is made up of a particular class of organizations, which play their part in society (businesses, government agencies, families, and schools). The fundamental argument that supports this theory is presented by Friedman (1962), who states that organizations are specialized to perform certain functions, and society can only get benefits if organizations do not realize multifunctional goals. Aupperle (1984) finds a trade-off in the managerial analysis process regarding the company's economic and ethical responsibilities. This trade-off is defined as "separation thesis", and it expects the possibility of taking business decisions that do not imply ethical and social consequences (Harris and Freeman, 2008). Wood (2010) notes that research on the relationship between CSP and CFP and "business cases" are based on a normative and systematic vision of the CSP, as it is made up of a series of policies and actions that companies should implement in addition to commitment for the achievement of economic objectives.

\subsection{The Relationship Between CSP-CFP}

Numerous studies have analysed the relationship between CSP and CFP, but the results of empirical studies are ambiguous, because some authors show a negative relationship between CSP and CFP, other authors a neutral or positive or a non-constant relationship. Indeed, some meta-analyses show the existence of a modest positive relationship between the two performances measures, while at the same time detecting high heterogeneity of results (Griffin and Mahon, 1997; Margolis and Walsh, 2003; Orlizky et al., 2003).

The positive relationship is explained by different propositions (Al-Tuwaijri, Christensen, and Hughes Ii, 2004; Hart and Ahuja, 1996; Judge and Douglas, 1998; Montabon, Sroufe, and Narasimhan, 2007; Russo and Fouts, 1997; Sroufe, 2003; Stanwick and Stanwick, 1998).

Waddock and Graves (1997b) argued the existence of a direct relationship between explicit costs (i.e., payment of interest to the holders of a series of contracts) and implicit costs of a company (i.e., product quality or safety costs). The authors suggested that attempts to reduce implicit costs of socially irresponsible actions would lead to an increase in explicit costs. Preston and O'Bannon (1997) provided a "social impact hypothesis" that links the ability to know the expectations of various stakeholders to a positive impact on financial performance. The positive relation may be justified with the assumption that costs incurred for CSP programs are only minimally comparable to potential benefits. For instance, costs incurred to provide benefits to employees can be considerably lower than the earned productivity. Moreover, the good management of a company should adopt effective policies and activities that could affect the determinants of the social and financial performance (Waddock and Graves, 1997a). Finally, a strong CFP can create slack resources that can be used for ethical and social programs, which increase the CSP (Waddock and Graves, 1997a; Preston and O'Bannon, 1997). Waddock and Graves (1997a) explain the existence of a positive relationship between CSP and CFP, with a combination of slack resources and good management, which determines a "virtuous circle" between CSP and CFP.

Part of the literature argues that CFP is negatively associated with CSP (Blacconiere and Patten, 1994; Jaggi and Freedman, 1992; Cordeiro and Sarkis, 1997; Yu, Ting, and Wu, 2009). The negative relationship is explained by neoclassical economists, who suggest that the social and environmental activities determine the use of the company resources, which are consequently not used to reach profit and therefore, to create value for shareholders (Friedman, 1970; Waddock and Graves, 1997b; Preston and O'Bannon, 1997).

Preston and O'Bannon (1997), through the formulation of the "managerial opportunism hypothesis", stated that, in case of positive financial performance, managers tend to reduce expenses for the social performance, thereby increasing short-term profitability and, consequently, increasing their remuneration, which is linked to short-term profitability.

Other studies have established that the relationship between CSP and CFP cannot be proved due to the complex relationship between company and society (Lorraine, Collison, and Power, 2004; King and Lenox, 2001; Murray, Sinclair, Power, and Gray, 2006).

Finally, some studies have found a relationship between CSP and CFP that is not constant over time and may assume the form of a "U" or an "inverted $U$ " (Bowman and Haire, 1975).

The discordant results in the literature determine the need of a better comprehension of the relationship between the two measures of performance (Griffin and Mahon, 1997; Margolis and Walsh, 2003; Rowley and Berman, 2000; Margolis, Elfenbein, and Walsh, 2007). The motivation shown in the literature can be linked to the critical factors referred to the multi-sector studies, the problems of measurement and the causal direction. 
Most studies use multi-sector samples, but the main disadvantage of this approach derives from the assumption that the specific characteristics of a single sector make the CSP related to the internal characteristics and external demands (Griffin and Mahon, 1997). Furthermore, different sectors exhibit heterogeneous configurations of stakeholders, with different degrees of activism and attention to the various problems. Wood and Jones (1995) noted the need to associate appropriate social and financial performance measures to stakeholders. The nature of stakeholder actions is an important factor affecting the CSP, as it determines different policies and activities of the company based on the type of action that stakeholders have requested (Rowley and Berman, 2000). Simpson and Kohers (2002) state that focusing on one single sector allows focusing on the internal validity, rather than on the external validity of a multi-sector analysis.

Regarding the measurement problems, the first empirical studies refer to indicators unable to grasp the multidimensional construct of the CSP, appointed by Wood and Jones (1995) "stakeholder mismatching" (Aupperle et al., 1985; Griffin and Mahon, 1997). The first empirical analyses were carried out by taking, as measures of CSP, indicators that detect individual components of corporate social responsibility. Carroll (2000) states that CSP should be measured through a comprehensive assessment of the social performance of the company, relative to the major social problems of its stakeholders. Numerous scholars support a multidimensional and complex CSP construct (Wartick and Cochran, 1985; Wood, 1991; Roman, Hayibor, and Agle, 1999; Griffin and Mahon, 1997; Swanson, 1999; Rowley and Berman, 2000). Measures such as Fortune Reputation Survey, the KLD index and the Domini 400 Social Index (Hillman and Keim, 2001) are used to identify indicators consistent with this theoretical construct. According to Simpson and Kohers (2002), a problem linked to these measures is connected to the impossibility of obtaining a representative sample extracted from a specific sector.

Finally, concerning the causal direction, Waddock and Graves (1997a) explain the existence of a positive relationship between CSP and CFP with a combination of slack resources and good management, which determines a "virtuous circle" between CSP and CFP. Good management approach holds that good corporate managers increase shareholder value by seeking competitive advantage through the satisfaction of stakeholders' expectations, concerning social responsibility issues (Miles and Covin, 2000). Slack resources approach, on the other hand, postulated that firms with better financial performance are able to allocate more slack sources to CSR policies and activities (Waddock and Graves, 1997a). Finally, Waddock and Graves (1997a) point out the possible existence of a "virtuous circle", in which better CFP results in improved corporate social performance (CSP) and improved CSP leads to better CFP. However, these arguments assert a direct relationship between the two performance measures, but their causal relationship still seems doubtful (Soana, 2011).

\subsection{Corporate Social Responsibility in the Banking Sector}

The banking system plays a fundamental role in economic development, and its safety and soundness over time generate important benefits for society (Shen and Lee, 2006; Beck, Demirgüç-Kunt, and Levine, 2010). Wu and Shen (2013) suggest that the nature of bank activity, characterized by the use of resources obtained from non-proprietary stakeholders, determines the obligation to provide feedback to the community more frequently than other industries.

The relief of intermediation performed by banks involves controls by the supervisory authorities, governments, academics and society itself regarding the overall activity including CSR activities. Banks are aware of the specificity of their business, based on the relationship of trust with the public and this awareness explains the presence of a CSR section in the annual financial statements (Wu and Shen, 2013). Following one of the most profound financial crises in history, which directly involved all the major banks in the world and undermined their credibility and reputation, CSR is perceived as a strategy to re-establish bank's credibility (Hsu, 2012; Schultz, Castelló, and Morsing, 2013). The banking sector's commitment to ethical policies and activities has important implications (Forcadell and Aracil, 2017). Non-responsible companies pay a higher cost to obtain financial resources than companies engaged in social activities, because investments in CSR may reduce the risk and increase the attractiveness of potential lenders (Goss and Roberts, 2011). Consequently, the bank's involvement in CSR practices determines the benefits for the bank itself (Polychronidou, Ioannidou, Kipouros, Tsourgiannis, and Simet, 2014), and promotes the adoption of sustainable practices by potential applicants, generating a positive impact on sustainable growth (Dorasamy, 2013).

Studies on the relationship between CSR and CFP in the banking sector are limited (Forcadell and Aracil, 2017; Goyal, Rahman, and Kazmi, 2013; Wu and Sheng, 2013; Simpson and Kohers, 2002; Scholtens and Dam, 2007; Chih, Chih, and Chen, 2010; Soana, 2011; Carnevale and Mazzuca, 2014; Mallin, Farag, and Ow-Yong, 2014; Esteban-Sanchez, de la Cuesta-Gonzalez, and Paredes-Gazquez, 2017). Scholtens and Dam (2007) compare the 
commitment in CSR policies, observing that the banks that adopt the Equator Principles pursue important CSR policies but register lower Return on assets (Roa). Wu and Shen (2013) test the relationship between the CSP and CFP in the global banking sector, analysing the reasons that drive banks to adopt CSP measures: strategic, altruistic and greenwashing reasons. The authors point out the existence of a positive, uncertain or neutral relationship with the financial performance, according to the strategic reasons that lead the bank managers to undertake socially responsible activities and policies. Carnevale e Mazzuca (2014), using a sample of European banks, reveal the positive influence of the publication of a bank sustainability report on the share price. Forcadell and Aracil (2017) analyse the impact of the reputation-improved through CSR policies - on the financial performance of European banks listed on the Dow Jones Sustainability Index (DJSI). Results show that banks' efforts to build a reputation deriving from the CSR programs determine benefits on financial performance.

\subsection{Theoretical Framework and Hypotheses Development}

The stakeholder theory, tested in the good management approach, assumes that the consolidation of relations with the primary stakeholders, through ethical activities and policies, allows companies to increase financial performance (Freeman, 1983; Orlitzky et al., 2003; Miles and Covin, 2000). In line with the reference literature, it is possible to formulate the following research hypothesis:

HY1: The bank's social performance positively influences its financial performance.

The slack resources approach postulates that CSP may be linked to prior firm financial performance (Cyert and March, 1963; Ullmann, 1985). The CSP policies and activities generate significant costs; consequently, more profitable firms may be more willing to engage these costs in the future (Parket and Eibert, 1975; Ullmann, 1985). In contrast, less profitable firms may be less willing to assume socially responsible actions. According to the reference literature, it is possible to formulate the following research hypothesis:

HY2: The bank's financial performance positively influences its social performance.

The literature suggests that a "virtuous circle" exists, generated by a combination of the slack resources and good management approaches, which determines that increased CSP leads to improved financial performance and vice versa (Waddock and Graves, 1997a; Hillman and Keim, 2001; Nelling and Webb, 2009; Zhao and Murrell, 2016). The "virtuous circle" between CSP and CFP is tested in the banking sector, formulating the following research hypothesis:

HY3: The combination of the good management approach and the slack resources approach, which determines the existence of a "virtuous circle" between the two performance measures in the banking sector.

\section{Methodology}

In line with the reference literature, a panel data analysis is used to verify the research hypotheses. The key independent variables are delayed by one period to check reverse causality. This estimation strategy allows limiting the problems of endogeneity and multicollinearity.

To verify the first research hypothesis the following model is implemented:

$$
\text { CFP }_{i t}=\alpha+\beta_{1} \text { CSP }_{i t-1}+\beta_{2} \operatorname{lnTA}_{i t}+\beta_{3} \text { Lev }_{i t}+\beta_{4} \text { LoanDep }_{i t}+\beta_{5} \text { CostIncom }_{i t}+\beta_{6} \text { Cover }_{i t}+\beta_{7} \operatorname{lnINT}_{i t}+\eta_{i}+\varepsilon_{i t}
$$

To verify the second research hypothesis the following model is used:

$$
\operatorname{CSP}_{i t}=\alpha+\beta_{1} \text { CFP }_{i t-1+} \beta_{2} \operatorname{lnTA}_{i t}+\beta_{3} \text { Lev }_{i t}+\beta_{4} \text { LoanDep }_{i t}+\beta_{5} \text { CostIncom }_{i t}+\beta_{6} \text { Cover }_{i t}+\beta_{7} \operatorname{lnINT}_{i t}+\eta_{i}+\varepsilon_{i t}
$$

The existence of a "virtuous circle" between CSP and CFP-third research hypothesis-occurs if the previous two research hypotheses are confirmed by the empirical results.

If both hypotheses are confirmed, an increase in CSP can be associated with an increase in the CFP, which simultaneously generates slack resources that can be used for socially responsible programs and activities, determining the improvement in the CFP and configuring the "virtuous circle".

In order to test the research hypotheses, a Pooled model is carried out supported by the results of the collinearity and heteroskedasticity tests. In order to improve the consistency of the estimates the Hausman test is carried out to support the choice between the panel analysis with fixed effects or with random effects and the analysis is performed with robust standard errors.

\subsection{Variables}

The dependent and independent variables are described below.

1). Corporate social performance 
The CSP variable is the Equal-weighted rating, provided by Thomson Reuters, determined by the weighting of the company's performance in the four fundamental areas of economic, environmental, social and corporate governance. The validity of the Thomson Reuters Asset4 database is supported in the literature (Cheng, Ioannou, and Serafeim, 2014; Semenova and Hassel, 2016).

2). Corporate financial performance

The CFP is represented by the Return on average Assets (ROAA) (Aupperle et al., 1985; Barnett and Salomon, 2012; Simpson and Kohers, 2002; Soana, 2011; Van der Laan, Van Ees, and Van Witteloostuijn, 2008). This accounting-based performance measure is able to record the ability of banks to generate income based on the total capital employed, therefore, returns generated from the assets financed by the bank (Simpson and Kohers, 2002).

3). Control variables

The control variables refer to the financial characteristics of banks. The ratio between the book value of the equity and total liabilities (Lev) detects the capital adequacy of the bank (Waddock and Graves, 1997a; Wu and Sheu, 2013). The size of the company-measured by the logarithm of total assets $(\ln T A)$ (Carnevale and Mazzuca, 2014; Lo and Sheu, 2007; Simpson and Kohers, 2002; Waddock and Graves, 1997a)-is considered a determinant of social and financial performance (Ullman, 1985). Further control variables, classified by Wu and Shen (2013) among the bank's main characteristics, are the ratio of loans to deposits (LoanDep), the cost to income ratio (CostInco) and, finally, the ratio between reserves for loan losses and non-performing loans (Cover). Finally, we consider the logarithm of the total of intangible resources (InINT), which are fundamental for the performance of banking activities (Forcadell and Aracil, 2017).

\subsection{Sample and Data}

The selected sample consists of 71 European listed banks (EU28), in the period between 2011 and 2015. The data referring to the measure of Corporate Social Performance are obtained from the Thomson Reuters DataStream database in the ASSET4 section. The financial variables were exported from the Orbis Bureau van Dijk database.

The descriptive statistics of the variables are shown in Table number 1.

Table 1. Descriptive statistics

\begin{tabular}{lccccc}
\hline & OBSERVATIONS & MEAN & STD.DEV. & MIN & MAX \\
\hline ROAA & 324 & 0,1585 & 1,2357 & $-7,154$ & 3,135 \\
CSP & 324 & 64,1757 & 31,9504 & 2,85 & 96,57 \\
TA & 325 & $3,61 \mathrm{e}+08$ & $5,05 \mathrm{e}+08$ & 1171375 & $2,04 \mathrm{e}+09$ \\
LEV & 325 & 7,8556 & 4,4004 & $-2,221$ & 27,245 \\
LOANDEP & 315 & 66,1072 & 15,9638 & 18,285 & 92,244 \\
COSTINCO & 319 & 62,9263 & 15,9039 & 37,707 & 161,916 \\
COVER & 315 & 60,2397 & 18,9015 & 30,528 & 148,685 \\
INT & 321 & 2895820 & 4902410 & 7297,298 & $2,62 \mathrm{e}+07$ \\
\hline
\end{tabular}

We note that the CFP, expressed by the ROAA variable, is between a minimum of $-7.154 \%$ and a maximum of $3.135 \%$, with an average of $0.1585 \%$ showing a wide variability of profitability during the reference period. This high variability could be explained by the difficulties that banks faced during the 2008 financial crisis and the sovereign debt crisis in the period 2011-2012.

The CSP is between a minimum of $2.85 \%$ and a maximum of $96.57 \%$, with an average of $64.17 \%$ demonstrating a wide variability in the CSP of the banks but, on average, a positive performance.

The correlation analysis between the variables is shown in Table 2 . 
Table 2. The correlation matrix

\begin{tabular}{|c|c|c|c|c|c|c|c|c|}
\hline & ROAA & CSP & TA & LEV & LOANDEP & COSTINCO & COVER & INT \\
\hline ROAA & 1,00 & & & & & & & \\
\hline CSP & $-0,09$ & 1,00 & & & & & & \\
\hline TA & $-0,43$ & $0,50 * * *$ & 1,00 & & & & & \\
\hline LEV & $0,41 * * *$ & $-0,24 * * *$ & $-0,35 * * *$ & 1,00 & & & & \\
\hline LOANDEP & 0.06 & $-0,32 * * *$ & $-0,67 * * *$ & $0,30 * * *$ & 1,00 & & & \\
\hline COSTINCO & $-0,44 * * *$ & $0,12 * *$ & $0,22 * * *$ & $-0,29 * * *$ & $-0,21 * * *$ & 1,00 & & \\
\hline COVER & $0,10^{*}$ & $-0,11 *$ & $-0,14 * *$ & $0,14 * *$ & 0,01 & 0,08 & 1,00 & \\
\hline INT & $-0,01$ & $0,44 * * *$ & $0,87 * * *$ & $-0,25 * * *$ & $-0,61 * * *$ & $0,18 * * *$ & $-0,17 * * *$ & 1,00 \\
\hline
\end{tabular}

Statistical Significance: $* \mathrm{p}<0.10, * * \mathrm{p}<0.05, * * * \mathrm{p}<0.01$.

\section{Results}

The results of the first econometric model (1) are shown in Table 3. Following the results of the Hausman test, we comment the Fixed Effect model.

Table 3. Results for the good management approach, dependent variable: ROAA

\begin{tabular}{|c|c|c|c|}
\hline & POOLED OLS & RANDOM EFECTS & FIXED EFFECTS \\
\hline \multirow{2}{*}{ CONSTANT } & 0,1420 & 3,0740 & 14,2565 \\
\hline & $(1,6252)$ & $(2,1055)$ & $(10,1016)$ \\
\hline \multirow{2}{*}{ LAGCSP } & 0,0001 & 0,0043 & $0,0188 * *$ \\
\hline & $(0,0024)$ & $(0,0032)$ & $(0,0075)$ \\
\hline \multirow{2}{*}{ LNINT } & 0,0588 & $0,1570 * *$ & $0,4452 * * *$ \\
\hline & $(0,0580)$ & $(0,0707)$ & $(0,1469)$ \\
\hline \multirow{2}{*}{ LNTA } & 0,0307 & $-0,1730$ & $-1,0455^{*}$ \\
\hline & $(0,0949)$ & $(0,1207)$ & $(0,5601)$ \\
\hline \multirow{2}{*}{ COVER } & 0,0022 & $-0,0048$ & $-0,0158 * *$ \\
\hline & $(0,0034)$ & $(0,0043)$ & $(0,0079)$ \\
\hline \multirow{2}{*}{ LEV } & $0,1228 * * *$ & $0,1083 * * *$ & $0,1103 * *$ \\
\hline & $(0,0198)$ & $(0,0214)$ & $(0,0425)$ \\
\hline \multirow{2}{*}{ COSTINCO } & $-0,0308 * * *$ & $-0,0337 * * *$ & $-0,0269 * *$ \\
\hline & $(0,0039)$ & $(0,0044)$ & $(0,0106)$ \\
\hline \multirow{2}{*}{ LOANDEP } & $-0,0079 *$ & $-0,0078$ & 0,0008 \\
\hline & $(0,0043)$ & $(0,0061)$ & $(0,0100)$ \\
\hline$R^{2} A D J U S T E D$ & 0.4543 & 0,4374 & 0,5041 \\
\hline OBSERVATIONS & 223 & 223 & 223 \\
\hline \multirow{2}{*}{$F T E S T$} & 27,40 & 157,95 & 4,18 \\
\hline & $(0,000)$ & $(0,000)$ & $(0.0008)$ \\
\hline
\end{tabular}

Statistical significance: $* \mathrm{p}<0.10, * * \mathrm{p}<0.05, * * * \mathrm{p}<0.01$, the value of the standard error is shown in brackets.

The first model shows a statistically significant positive relationship between the Corporate Financial Performance measured by the Return on Average Asset (ROAA)-and the CSP referring to the previous year. These results are in line with previous literature which sustains the existence of a positive relationship, justified by the greater attention of the bank's managers towards a series of non-proprietary primary stakeholders, generating positive effects on financial performance. These results support the first research hypothesis, which is based on the good management approach.

According to the control variables a statistically significant and positive relationship is observable between the dependent variable and the logarithm of the intangibles (InINT, p-value <0.01) and the equity/liability ratio (Lev, p-value $<0.05)$. The size, measured by the logarithm of total assets $(\ln T A$, p-value $<0.1)$, the coverage ratio $(C o v e r$, p-value $<0.05)$ and the cost income ratio (CostInco, p-value $<0.01)$ show significant and negative relationships with 
the bank's CFP. Therefore, for larger listed European banks, the better efficiency in cost management and a smaller size may be associated with the higher profitability of assets.

To verify the second research hypothesis the results of the second econometric model (2) are shown in Table 4. Following the results of the Hausman test, we comment the Random Effect model.

Table 4. Results for the slack resources approach, dependent variable: CSP

\begin{tabular}{|c|c|c|c|}
\hline & POOLED OLS & RANDOM EFECTS & FIXED EFFECTS \\
\hline \multirow{2}{*}{ CONSTANT } & $-250,788 * * *$ & $-282,8681 * * *$ & $-182,9783$ \\
\hline & $(42,0896)$ & $(47,0836)$ & $(123,472)$ \\
\hline \multirow{2}{*}{ LAGROA } & $-2,3329 * *$ & $-2,0645 * * *$ & $-1,6664 * *$ \\
\hline & $(1,3951)$ & $(0,7653)$ & $(0,7987)$ \\
\hline \multirow{2}{*}{ LNINT } & $3,4922 * *$ & 0,9307 & $-1,0055$ \\
\hline & $(1,5630)$ & $(1,4327)$ & $(1,7738)$ \\
\hline \multirow{2}{*}{ LNTA } & $12,7805 * * *$ & $16,1418 * * *$ & $11,9176^{* *}$ \\
\hline & $(2,5170)$ & $(2,6807)$ & $(6,9237)$ \\
\hline \multirow{2}{*}{ COVER } & $0,2156^{* *}$ & 0,0622 & 0,0275 \\
\hline & $(0,0968)$ & $(0,0895)$ & $(0,1002)$ \\
\hline \multirow{2}{*}{ LEV } & 0,9028 & $1,6222 * * *$ & $1,2876^{* * *}$ \\
\hline & $(0,6052)$ & $(0,4383)$ & $(0,4966)$ \\
\hline \multirow{2}{*}{ COSTINCOM } & $-0,0559$ & $-0,0779$ & $-0,1068$ \\
\hline & $(0,1120)$ & $(0,0820)$ & $(0,0898)$ \\
\hline \multirow{2}{*}{ LOANDEP } & $0,2356 * *$ & $0,3374 * *$ & $0,5432 * * *$ \\
\hline & $(0,1176)$ & $(0,1412)$ & $(0,1878)$ \\
\hline$R^{2} A D J U S T E D$ & 0,4892 & 0,1305 & 0,1522 \\
\hline OBSERVATIONS & 219 & 81,31 & 219 \\
\hline \multirow{2}{*}{ F TEST } & 30,82 & 157,95 & 3,85 \\
\hline & $(0,0000)$ & $(0,0000)$ & $(0.0007)$ \\
\hline
\end{tabular}

Statistical significance: $* \mathrm{p}<0.10, * * \mathrm{p}<0.05, * * * \mathrm{p}<0.01$, the value of the standard error is shown in brackets.

A statistically significant and negative relationship is observable between the Corporate Social Performance measured by the Equal-weighted rating-and the financial performance (ROAA) referred to the previous year. These results do not support the second research hypothesis based on the slack resources approach, but may support the managerial opportunistic hypothesis. According to the latter, in the presence of strong financial performance, managers tend to reduce the expense for Corporate Social Performance in order to increase profitability in the short term and, consequently, increase their personal salary, directly linked to the short-term profitability of the company.

Based on the results presented, it is finally possible to state that even the third research hypothesis is not verified. Indeed, there is no positive influence of the CFP on the CSP (slack resources approach) and this excludes the existence of a "virtuous circle" deriving from the combination of good management approach and slack resources approach, in the banking sector.

According to the control variables results show statistically significant and positive relationships among the dependent variable and the following controls: the size of the banks, measured by the logarithm of the total asset (p-value $<0.1$ ); the equity-liability ratio ( $\mathrm{p}$-value $<0.01$ ); the ratio between loans and deposits ( $\mathrm{p}$-value $<0.05$ ). The summary indications lead to the conclusion that higher and more solid banks may show better social performance.

\section{Conclusions}

The present study focuses on the existence of a "virtuous circle" between Corporate Social Performance and Corporate Financial Performance for the European banking sector.

The results of the econometric analysis support the first research hypothesis (good management approach) showing the existence of a positive influence of Corporate Social Performance on Corporate Financial Performance. These results confirm the reference literature that supports the social impact hypothesis, which attributes to the ability to know and satisfy the needs of the various stakeholders a direct impact on the financial performance of companies. 
The second research hypothesis, referring to the existence of a positive influence of the Corporate Financial Performance on the Corporate Social Performance (slack resources approach) is not verified by the results of the empirical analysis, showing a significant and negative relationship between the two variables. This empirical evidence could support the managerial opportunistic hypothesis, which postulates that, in the presence of good financial performance, managers are likely to reduce expenses for social and environmental programs, in order to increase short-term profitability, precisely because their personal remuneration may be linked to the intermediary's profitability in the short term.

The third research hypothesis referring to the existence of a "virtuous circle", deriving from the combination of the two previously illustrated approaches, is not verified, because the good management approach is supported by the empirical results, but the slack resources approach is not supported by the analysis. Therefore, it is not possible to support the "circular" relationship between the two performance measures.

The results are inconsistent with the reference literature on the topic (Waddock and Graves, 1997a; Nelling and Webb, 2009) and could lead arguing that bank managers can see the CSP as a strategy that generates value for the bank. However, the value generated is not allocated for social and environmental measures, since it is intended to increase the intermediary's profitability in the short term and, arguably, the remuneration of managers.

In order to improve the understanding of the relationship between CSP and CFP, future studies could test the existence of mediating mechanisms, i.e. examine the possible mediating role of intangible variables as reputation, organizational culture and human capital.

\section{References}

Aguinis, H. (2011). Organizational responsibility: Doing good and doing well. In S. Zedeck (Ed.), APA handbook of industrial and organizational psychology (Vol. 3, pp. 855-879). Washington, DC: American Psychological Association. https://doi.org/10.1037/12171-024

Aguinis, H., \& Glavas, A. (2012). What we know and don't know about corporate social responsibility a review and research agenda. Journal of Management, 38(4), 932-968. https://doi.org/10.1177/0149206311436079

Al-Tuwaijri, S.A., Christensen, T.E., \& Hughes Ii, K.E. (2004). The relations among environmental disclosure, environmental performance, and economic performance: a simultaneous equations approach. Accounting, Organizations and Society, 29(5-6), 447-471. https://doi.org/10.1016/S0361-3682(03)00032-1

Aupperle, K.E. (1984). An empirical measure of corporate social orientation. Research in corporate social performance and policy, 6, 27-54.

Aupperle, K.E., Carroll, A.B., \& Hatfield, J.D. (1985). An empirical examination of the relationship between corporate social responsibility and profitability. Academy of Management Journal, 28(2), 446-463. https://doi.org/10.2307/256210

Bakar, A., Sheikh, A., \& Ameer, R. (2011). Readability of corporate social responsibility communication in Malaysia. Corporate Social Responsibility and Environmental Management, 18(1), 50-60. https://doi.org/10.1002/csr.240

Barnett, M.L., \& Salomon, R.M. (2012). Does it pay to be really good? Addressing the shape of the relationship between social and financial performance. Strategic Management Journal, 33(11), 1304-1320. https://doi.org/10.1002/smj.1980

Beck, T., Demirgüç-Kunt, A., \& Levine, R. (2010). Financial institutions and markets across countries and over time: The updated financial development and structure database. The World Bank Economic Review, 24(1), 77-92. https://doi.org/10.1093/wber/lhp016

Berle, A.A. (1931). Corporate powers as powers in trust. Harvard Law Review, 44(7), 1049-1074. https://doi.org/10.2307/1331341

Blacconiere, W.G., \& Patten, D.M. (1994). Environmental disclosures, regulatory costs, and changes in firm value. Journal of Accounting and Economics, 18(3), 357-377. https://doi.org/10.1016/0165-4101(94)90026-4

Bontis, N., \& Serenko, A. (2009). A follow-up ranking of academic journals. Journal of Knowledge Management, 13(1), 16-26. https://doi.org/10.1108/13673270910931134

Boulding, K.E. (1956). General systems theory-the skeleton of science. Management science, 2(3), 197-208. https://doi.org/10.1287/mnsc.2.3.197 
Bowen, H.R. (1953). Social responsibilities of the businessman. New York: Harper \& Row.

Bowman, E.H., \& Haire, M. (1975). A strategic posture toward corporate social responsibility. California management review, 18(2), 49-58. https://doi.org/10.2307/41164638

Carnevale, C., \& Mazzuca, M. (2014). Sustainability report and bank valuation: evidence from European stock markets. Business Ethics: A European Review, 23(1), 69-90. https://doi.org/10.1111/beer.12038

Carroll, A.B. (1979). A three-dimensional conceptual model of corporate performance. Academy of Management Review, 4(4), 497-505. https://doi.org/10.5465/AMR.1979.4498296

Carroll, A.B. (1999). Corporate social responsibility: Evolution of a definitional construct. Business \& Society, 38(3), 268-295. https://doi.org/10.1177/000765039903800303

Carroll, A.B. (2000). A commentary and an overview of key questions on corporate social performance measurement. Business \& Society, 39(4), 466-478. https://doi.org/10.1177/000765030003900406

Cheng, B., Ioannou, I., \& Serafeim, G. (2014). Corporate social responsibility and access to finance. Strategic Management Journal, 35(1), 1-23. https://doi.org/10.1002/smj.2131

Chih, H.L., Chih, H.H., \& Chen, T.Y. (2010). On the determinants of corporate social responsibility: International evidence on the financial industry. Journal of Business Ethics, 93(1), 115-135. https://doi.org/10.1007/s10551-009-0186-x

Cordeiro, J.J., \& Sarkis, J. (1997). Environmental proactivism and firm performance: evidence from security analyst earnings forecasts. Business Strategy and the Environment, 6(2), 104-114. https://doi.org/10.1002/(SICI)1099-0836(199705)6:2<104::AID-BSE102>3.0.CO;2-T

Cyert, R.M., \& March, J.G. (1963). A behavioral theory of the firm. Englewood Cliffs, NJ, 2, 169-187.

Dorasamy, N. (2013). Corporate Social Responsibility and Ethical Banking for Developing Economies. Journal of Economics and Behavioral Studies, 5(11), 777-785. http://hdl.handle.net/10321/1151

Elliot, S. (2011). Transdisciplinary perspectives on environmental sustainability: a resource base and framework for IT-enabled business transformation. Mis quarterly, 35(1), 197-236. https://doi.org/10.2307/23043495

Esteban-Sanchez, P., de la Cuesta-Gonzalez, M., \& Paredes-Gazquez, J.D. (2017). Corporate social performance and its relation with corporate financial performance: International evidence in the banking industry. Journal of cleaner production, 162, 1102-1110. https://doi.org/10.1016/j.jclepro.2017.06.127

Forcadell, F.J., \& Aracil, E. (2017). European Banks' Reputation for Corporate Social Responsibility. Corporate Social Responsibility and Environmental Management, 24(1), 1-14. https://doi.org/10.1002/csr.1402

Frederick, W.C. (1960). The growing concern over business responsibility. California Management Review, 2(4), 54-51. https://doi.org/10.2307/41165405

Frederick, W.C. (1994). From CSR1 to CSR2 the maturing of business-and-society thought. Business \& Society, 33(2), 150-164. https://doi.org/10.1177/000765039403300202

Freeman, R.E. (1983). Strategic management: A stakeholder approach. Advances in Strategic Management, 1(1), 31-60.

Friedman, M. (1962). Capitalism and freedom: With the assistance of Rose D. Friedman. University of Chicago Press.

Friedman, M. (1970). A theoretical framework for monetary analysis. Journal of Political Economy, 78(2), 193-238. https://doi.org/10.1086/259623

Galbreath, J., \& Shum, P. (2012). Do customer satisfaction and reputation mediate the CSR-FP link? Evidence from Australia. Australian Journal of Management, 37(2), 211-229. https://doi.org/10.1177/0312896211432941

Goss, A., \& Roberts, G.S. (2011). The impact of corporate social responsibility on the cost of bank loans. Journal of Banking \& Finance, 35(7), 1794-1810. https://doi.org/10.1016/j.jbankfin.2010.12.002

Goyal, P., Rahman, Z., \& Kazmi, A.A. (2013). Corporate sustainability performance and firm performance research: Literature review and future research agenda. Management Decision, 51(2), 361-379. https://doi.org/10.1108/00251741311301867 
Griffin, J.J., \& Mahon, J.F. (1997). The corporate social performance and corporate financial performance debate: Twenty-five years of incomparable research. Business \& Society, 36(1), 5-31. https://doi.org/10.1177/000765039703600102

Harris, J.D., \& Freeman, R.E. (2008). The impossibility of the separation thesis: A response to Joakim Sandberg. Business Ethics Quarterly, 18(4), 541-548. https://doi.org/10.5840/beq200818437

Hart, S.L., \& Ahuja, G. (1996). Does it pay to be green? An empirical examination of the relationship between emission reduction and firm performance. Business Strategy and the Environment, 5(1), 30-37. https://doi.org/10.1002/(SICI)1099-0836(199603)5:1<30::AID-BSE38>3.0.CO;2-Q

Hillman, A.J., \& Keim, G.D. (2001). Shareholder value, stakeholder management, and social issues: What's the bottom line? Strategic Management https://doi.org/10.1002/1097-0266(200101)22:2<125::AID-SMJ150>3.0.CO;2-H

Hsu, K.T. (2012). The advertising effects of corporate social responsibility on corporate reputation and brand equity: Evidence from the life insurance industry in Taiwan. Journal of Business Ethics, 109(2), 189-201. https://doi.org/10.1007/s10551-011-1118-0

Jaggi, B., \& Freedman, M. (1992). An examination of the impact of pollution performance on economic and market performance: pulp and paper firms. Journal of Business Finance \& Accounting, 19(5), 697-713. https://doi.org/10.1111/j.1468-5957.1992.tb00652.x

Judge, W.Q., \& Douglas, T.J. (1998). Performance implications of incorporating natural environmental issues into the strategic planning process: an empirical assessment. Journal of Management Studies, 35(2), 241-262. https://doi.org/10.1111/1467-6486.00092

King, A.A., \& Lenox, M.J. (2001). Does it really pay to be green? An empirical study of firm environmental and financial performance: An empirical study of firm environmental and financial performance. Journal of Industrial Ecology, 5(1), 105-116. https://doi.org/10.1162/108819801753358526

Lima Crisóstomo, V., de Souza Freire, F., \& Cortes de Vasconcellos, F. (2011). Corporate social responsibility, firm value and financial performance in Brazil. Social Responsibility Journal, 7(2), 295-309. https://doi.org/10.1108/17471111111141549

Lo, S.F., \& Sheu, H.J. (2007). Is corporate sustainability a value-increasing strategy for business?. Corporate Governance: An International Review, 15(2), 345-358. https://doi.org/10.1111/j.1467-8683.2007.00565.x

Lorraine, N.H.J., Collison, D.J., \& Power, D.M. (2004). An analysis of the stock market impact of environmental performance information. Accounting Forum, 28(1), 7-26. https://doi.org/10.1016/j.accfor.2004.04.002

Maignan, I., \& Ferrell, O.C. (2004). Corporate social responsibility and marketing: An integrative framework. Journal of the Academy of Marketing Science, 32(1), 3-19. https://doi.org/10.1177/0092070303258971

Mallin, C., Farag, H., \& Ow-Yong, K. (2014). Corporate social responsibility and financial performance in Islamic banks. Journal of Economic Behavior \& Organization, 103, S21-S38. https://doi.org/10.1016/j.jebo.2014.03.001

Margolis, J.D., \& Walsh, J.P. (2003). Misery loves companies: Rethinking social initiatives by business. Administrative Science Quarterly, 48(2), 268-305. https://doi.org/10.2307/3556659

Margolis, J.D., Elfenbein, H.A., \& Walsh, J.P. (2007). Does it pay to be good? A meta-analysis and redirection of research on the relationship between corporate social and financial performance. Ann Arbor, 1001. https://doi.org/10.2139/ssrn.1866371

McGuire, J.W. (1969). The changing nature of business responsibilities. The Journal of Risk and Insurance, 36(1), 55-61. https://doi.org/10.2307/251140

Miles, M.P., \& Covin, J.G. (2000). Environmental marketing: A source of reputational, competitive, and financial advantage. Journal of Business Ethics, 23(3), 299-311. https://doi.org/10.1023/A:1006214509281

Mishra, S., \& Suar, D. (2010). Does corporate social responsibility influence firm performance of Indian companies?. Journal of Business Ethics, 95(4), 571-601. https://doi.org/10.1007/s10551-010-0441-1

Montabon, F., Sroufe, R., \& Narasimhan, R. (2007). An examination of corporate reporting, environmental management practices and firm performance. Journal of Operations Management, 25(5), 998-1014. https://doi.org/10.1016/j.jom.2006.10.003 
Murray, A., Sinclair, D., Power, D., \& Gray, R. (2006). Do financial markets care about social and environmental disclosure? Further evidence and exploration from the UK. Accounting, Auditing \& Accountability Journal, 19(2), 228-255. https://doi.org/10.1108/09513570610656105

Nelling, E., \& Webb, E. (2009). Corporate social responsibility and financial performance: the "virtuous circle" revisited. Review of Quantitative Finance and Accounting, 32(2), 197-209. https://doi.org/10.1007/s11156-008-0090-y

Oeyono, J., Samy, M., \& Bampton, R. (2011). An examination of corporate social responsibility and financial performance: A study of the top 50 Indonesian listed corporations. Journal of Global Responsibility, 2(1), 100-112. https://doi.org/10.1108/20412561111128555

Orlitzky, M., Schmidt, F.L., \& Rynes, S.L. (2003). Corporate social and financial performance: A meta-analysis. Organization Studies, 24(3), 403-441. https://doi.org/10.1177/0170840603024003910

Parket, I.R., \& Eilbirt, H. (1975). The practice of business social responsibility: The underlying factors. Business Horizons, 18(4), 5-10. https://doi.org/10.1016/0007-6813(75)90019-1

Parsons, T. (1991). The social system. Psychology Press.

Polychronidou, P., Ioannidou, E., Kipouros, A., Tsourgiannis, L., \& Simet, G.F. (2014). Corporate Social Responsibility in Greek Banking Sector-An Empirical Research. Procedia Economics and Finance, 9, 193-199. https://doi.org/10.1016/S2212-5671(14)00020-3

Preston, L.E., \& O'bannon, D.P. (1997). The corporate social-financial performance relationship: A typology and analysis. Business \& Society, 36(4), 419-429. https://doi.org/10.1177/000765039703600406

Roman, R.M., Hayibor, S., \& Agle, B.R. (1999). The relationship between social and financial performance: Repainting a portrait. Business \& Society, 38(1), 109-125. https://doi.org/10.1177/000765039903800105

Rowley, T., \& Berman, S. (2000). A brand new brand of corporate social performance. Business \& Society, 39(4), 397-418. https://doi.org/10.1177/000765030003900404

Russo, M.V., \& Fouts, P.A. (1997). A resource-based perspective on corporate environmental performance and profitability. Academy of Management Journal, 40(3), 534-559. https://doi.org/10.2307/257052

Scholtens, B., \& Dam, L. (2007). Cultural values and international differences in business ethics. Journal of Business Ethics, 75(3), 273-284. https://doi.org/10.1007/s10551-006-9252-9

Schultz, F., Castelló, I., \& Morsing, M. (2013). The construction of corporate social responsibility in network societies: A communication view. Journal of business ethics, 115(4), 681-692. https://doi.org/10.1007/s10551-013-1826-8

Semenova, N., \& Hassel, L.G. (2016). The moderating effects of environmental risk of the industry on the relationship between corporate environmental and financial performance. Journal of Applied Accounting Research, 17(1), 97-114. https://doi.org/10.1108/JAAR-09-2013-0071

Shen, C.H., \& Lee, C.C. (2006). Same financial development yet different economic growth: why?. Journal of Money, Credit and Banking, 1907-1944. https://doi.org/10.1353/mcb.2006.0095

Simpson, W.G., \& Kohers, T. (2002). The link between corporate social and financial performance: Evidence from the banking industry. Journal of Business Ethics, 35(2), 97-109. https://doi.org/10.1023/A:1013082525900

Soana, M.G. (2011). The relationship between corporate social performance and corporate financial performance in the banking sector. Journal of Business Ethics, 104(1), 133. https://doi.org/10.1007/s10551-011-0894-x

Sroufe, R. (2003). Effects of environmental management systems on environmental management practices and operations. Production and Operations Management, 12(3), 416-431. https://doi.org/10.1111/j.1937-5956.2003.tb00212.x

Stanwick, P.A., \& Stanwick, S.D. (1998). The relationship between corporate social performance, and organizational size, financial performance, and environmental performance: An empirical examination. Journal of Business Ethics, 17(2), 195-204. https://doi.org/10.1023/A:1005784421547

Swanson, D.L. (1999). Toward an integrative theory of business and society: A research strategy for corporate social performance. Academy of Management Review, 24(3), 506-521. https://doi.org/10.5465/AMR.1999.2202134 
Ullmann, A.A. (1985). Data in search of a theory: A critical examination of the relationships among social performance, social disclosure, and economic performance of US firms. Academy of Management Review, 10(3), 540-557. https://doi.org/10.5465/AMR.1985.4278989

Van der Laan, G., Van Ees, H., \& Van Witteloostuijn, A. (2008). Corporate social and financial performance: An extended stakeholder theory, and empirical test with accounting measures. Journal of Business Ethics, 79(3), 299-310. https://doi.org/10.1007/s10551-007-9398-0

Vogel, D.J. (2005). Is there a market for virtue? The business case for corporate social responsibility. California Management Review, 47(4), 19-45. https://doi.org/10.1177/000812560504700401

Waddock, S. (2004). Parallel universes: Companies, academics, and the progress of corporate citizenship. Business and Society Review, 109(1), 5-42. https://doi.org/10.1111/j.0045-3609.2004.00002.x

Waddock, S.A., \& Graves, S.B. (1997a). The corporate social performance-financial performance link. Strategic Management Journal, 303-319. https://doi.org/10.1002/(SICI)1097-0266(199704)18:4<303::AID-SMJ869>3.0.CO;2-G

Waddock, S.A., \& Graves, S.B. (1997b). Quality of management and quality of stakeholder relations: are they synonymous?. Business \& Society, 36(3), 250-279. https://doi.org/10.1177/000765039703600303

Wartick, S.L., \& Cochran, P.L. (1985). The evolution of the corporate social performance model. Academy of management review, 10(4), 758-769. https://doi.org/10.5465/AMR.1985.4279099

Wood, D.J. (1991). Corporate social performance revisited. Academy of Management Review, 16(4), 691-718. https://doi.org/10.5465/AMR.1991.4279616

Wood, D.J. (2010). Measuring corporate social performance: A review. International Journal of Management Reviews, 12(1), 50-84. https://doi.org/10.1111/j.1468-2370.2009.00274.x

Wood, D.J., \& Jones, R.E. (1995). Stakeholder mismatching: A theoretical problem in empirical research on corporate social performance. The International Journal of Organizational Analysis, 3(3), 229-267. https://doi.org/10.1108/eb028831

Wu, M.W., \& Shen, C.H. (2013). Corporate social responsibility in the banking industry: Motives and financial performance. Journal of Banking \& Finance, 37(9), 3529-3547. https://doi.org/10.1016/j.jbankfin.2013.04.023

Yu, V., Ting, H.I., \& Jim Wu, Y.C. (2009). Assessing the greenness effort for European firms: A resource efficiency perspective. Management Decision, 47(7), 1065-1079. https://doi.org/10.1108/00251740910978304

Zhao, X., \& Murrell, A.J. (2016). Revisiting the corporate social performance-financial performance link: A replication of Waddock and Graves. Strategic Management Journal, 37(11), 2378-2388. https://doi.org/10.1002/smj.2579 